\title{
Analysis of clinical and virologic features in Hepatitis B e Antigen (HbeAg)-negative and HbeAg-positive Egyptian chronic hepatitis B patients
}

\author{
Rabab Fouad ${ }^{1}$, Sherief Musa ${ }^{1}$, Dina Sabry ${ }^{2}$, Ahmad Salama $^{1}$, Shereen Abdel Alem ${ }^{1}$, Mira Atef ${ }^{1}$, Naglaa Zayed ${ }^{1}$ \\ 1. Endemic Medicine and Hepatology Department, Faculty of medicine, Cairo University, Cairo, Egypt. \\ 2. Medical Biochemistry and Molecular Biology Department, Faculty of Medicine, Cairo University, Cairo, Egypt.
}

\begin{abstract}
Background: $\mathrm{HBeAg-negative} \mathrm{chronic} \mathrm{hepatitis} \mathrm{B} \mathrm{infection} \mathrm{has} \mathrm{a} \mathrm{divergent} \mathrm{clinical} \mathrm{course} \mathrm{from} \mathrm{that} \mathrm{of} \mathrm{HBeAg-positive}$ infection.

Objectives: To analyze the frequency and to compare the different features of HBeAg-negative and HBeAg-positive chronic hepatitis B patients.

Methods: One hundred and twenty one Egyptian patients with chronic hepatitis B (CHB), underwent laboratory investigations and transient elastography (TE). Comparisons according to HBeAg status were conducted regarding their demographic, liver biochemical and virologic characters.

Results: 97 patients (80.2\%) were HBeAg-negative while 24 patients (19.8\%) were HBeAg-positive. HBeAg-negative patients were significantly older in age than CHBeAg-positive patients $(\mathrm{p}=0.001)$. ALT levels in HBeAg-negative patients were significantly lower than those in $\mathrm{HBeAg}$-positive patients $(\mathrm{p}=0.02)$, whereas serum albumin was lower in the HBeAg-positive group ( $\mathrm{p}=0.03)$. The percentage of HBV DNA higher than $20000 \mathrm{IU} / \mathrm{mL}$ in HBeAg-negative patients was lower than those in $\mathrm{HBeAg}$-positive patients $(\mathrm{p}=0.24)$. Stages of fibrosis by TE showed that $30.9 \%$ of $\mathrm{HBeAg}$-negative and $41.7 \%$ of $\mathrm{HBeAg}$-positive had a fibrosis score $>$ F2. Four patients $(3.3 \%)$ were diagnosed with HCC; all of whom were HBeAg-negative.

Conclusion: HBeAg-negative patients compared with HBeAg-positive patients had older age, lower ALT and serum HBVDNA levels, but more incidence of HCC.

Keywords: Hepatitis B; HBeAg; fibrosis; Egypt.

DOI: https://doi.org/10.4314/ahs.v20i2.13

Cite as: Fonad R, Musa S, Sabry D, Salama A, Alem SA, Atef M, Zayed N. Analysis of clinical and virologic features in Hepatitis B e Antigen (HbeAg)-negative and HbeAg-positive Egyptian chronic Hepatitis B patients. Afri Health Sci. 2020; 20(2): 649-655. https:/ / doi. org/10.4314/ahs.v20i2.13
\end{abstract}

\section{Introduction}

Hepatitis B virus (HBV) infection is a global health problem. Previous estimates had shown that 2 billion people have been infected worldwide, 360 millions suffer from chronic HBV infection resulting in over 470000 deaths from cirrhosis or liver cancer ${ }^{1}$. The prevalence of hepatitis B surface antigen (HBsAg) in Egypt is of intermediate endemicity (2-8\%). Nearly 2-3 million Egyptians are chronic carriers of $\mathrm{HBV}^{2}$.

\section{Corresponding author:}

Shereen Abdel Alem,

Faculty of Medicine, Cairo University,

Cairo, Egypt, post code11562.

Phone: +201225349001

ORCID of the corresponding

author: 0000-0002-3612-0130

Email: shery_2424@yahoo.com
The clinical course and outcome of chronic hepatitis $\mathrm{B}(\mathrm{CHB})$ vary among individuals, as pathogenesis is probably multifactorial, involving both viral and host factors ${ }^{3}$. The clinical spectrum ranges from subclinical to acute symptomatic hepatitis or, rarely, fulminant hepatitis during the acute phase and from the inactive HBV infection and chronic hepatitis of various degrees of histologic severity to cirrhosis and its complications during the chronic phase ${ }^{4}$.

The typical course of hepatitis B infection involves a hepatitis $\mathrm{B}$ e antigen ( $\mathrm{HBeAg}$ )-positive phase due to socalled "wild type" HBV. The majority of HBeAg-positive patients have high serum HBV DNA and normal alanine transaminase (ALT) levels and show minimal changes on liver biopsy ${ }^{5}$. Subsequently, patients undergo seroconversion in which $\mathrm{HBeAg}$ is lost and antibodies to $\mathrm{HBeAg}$ (anti-HBe) appear ${ }^{6}$. After seroconversion, some patients enter the low-replicative phase 
characterized by normal serum ALT concentration and minimal histological changes ${ }^{7}$. Among some patients, immune pressure selects $\mathrm{HBV}$ variants unable to produce high amounts of the protein that bears the $\mathrm{HBe}$ epitope, leading to persistence of viral replication after loss of $\mathrm{HBeAg}$ with associated liver damage ${ }^{8}$.

There are a variety of mutations in the core promoter and pre-core region that can decrease or prevent the synthesis of $\mathrm{HBeAg}$ without adversely affecting the ability of the HBV to replicate ${ }^{9}$. The most common naturally occurring $\mathrm{HBV}$ genomic variant includes a precore (PC) stop codon single mutation (G1896A), which abolishes $\mathrm{HBeAg}$ production and double mutations in the basal core promoter (BCP) region (A1762T/ G1764A), which down-regulate HbeAg production ${ }^{10}$.

There are conflicting reports about the association of these mutations and severity of liver disease ${ }^{9}$. Infection with $\mathrm{HBeAg-negative} \mathrm{hepatitis} \mathrm{B} \mathrm{variants} \mathrm{is} \mathrm{presumed}$ to be associated with lower serum viral levels, higher intrahepatic necroinflammatory lesions, and more severe progression of disease, with frequent development of cirrhosis and/or HCC than is infection with $\mathrm{HBeAg}$-positive strains, indicating a stronger immune response against $\mathrm{HBeAg-negative} \mathrm{infection}{ }^{10}$. In addition, the clinical significance of these mutations remains to be defined in the context of antiviral therapy ${ }^{11}$. The aim of this study was to clarify the association of HBeAg status with serum HBV DNA levels, degree of liver damage or inflammation represented by ALT levels, and liver fibrosis progression, as well as other factors that affect these clinical parameters.

\section{Patients and methods}

Our study was a cross-sectional one that was conducted on 121 treatment-naïve chronic hepatitis B (CHB) patients, attending the outpatients' clinics of the Endemic Medicine Department, Faculty of Medicine, Cairo University and Cairo Fatemic Hospital, Ministry of Health and Population (MOHP) over the period from January 2013 to December 2013. The criteria for diagnosis of $\mathrm{CHB}$ were the presence of positive $\mathrm{HbsAg}$ for more than six months.

Inclusion criteria: Adult ( $>18$ years old) symptomatic or asymptomatic chronic HBV patients of both genders within the clinical spectrum of chronic HBV infection. Exclusion criteria: $\mathrm{HCV}$ Co-infection, $\mathrm{HBV}$ patients who had received or currently under anti-viral therapy (interferon or nucleos(t)ide analogues), alcohol, or illicit drug abuse.

Patients were examined for their demographic data, $\mathrm{HBV}$ related risk factors, radiological and laboratory data were collected. Blood samples were investigated for liver biochemical profile and re-detection of hepatitis $B$ virus surface antigen ( $\mathrm{HBs} \mathrm{Ag}$ ), antibodies against $\mathrm{HB}$ e antigen (anti-HBe), Hepatitis B e antigen (HBe Ag) by ELISA (Abott Murex Diagnostic Division). Hepatitis B virus DNA levels were quantified using COBAS TaqMan HBV test (Roche Diagnostics).

\section{Genotyping of HBV}

The identification of HBV genotypes was performed by polymerase chain reaction-restriction fragment length polymorphism (PCR-RFLP) of the surface gene of HBV. Briefly, DNA was extracted from $200 \mathrm{ml}$ of serum samples by using the QIAamp blood kit (Qiagen, Chatsworth, CA), and the fragment of the $\mathrm{HBV}$ genome between nucleotide positions 256 and 796 was then amplified. The PCR products were subsequently treated with restriction enzymes. After incubation, the samples were run on a 3\% agarose gel and stained by ethidium bromide. Genotypes of HBV could be identified by the restriction patterns of DNA fragments.

\section{Transient elastography (TE)}

Transient elastography (TE) was performed by a single operator with the Fibroscan device (Echosens, Paris, France) which incorporates a 5-MHz ultrasound transducer probe mounted on the axis of a vibrator. The vibrator generates a completely painless vibration (with a frequency of $50 \mathrm{~Hz}$ and amplitude of $2 \mathrm{~mm}$ ), which leads to an elastic shear wave propagating through the skin and subcutaneous tissue to the liver. The shear wave velocity (expressed in kiloPascals- $\mathrm{kPa}$ ) is directly related to the stiffness of the tissue. On TE, liver fibrosis score (stage $)>2(\mathrm{~F}>2)$ was considered as cutoff value to show moderate to significant liver fibrosis ${ }^{12}$. Liver biopsy was done whenever indicated according to guidelines ${ }^{13}$.

Informed consent was obtained from all patients who participated in the study. The study was performed in accordance with the guidelines of the 1975 Declaration of Helsinki and the principles of Good Clinical Practice.

\section{Statistical analysis}

Complete pre-coded data were filled in using "Micro- 
soft Office Excel Software" program (2010) for windows. Data transferred for statistical analysis to the Statistical Package of Social Science Software program (SPSS), version 21.

Quantitative variables were expressed as mean and standard deviation, whereas qualitative ones were expressed as frequency and percentage. Comparison between groups was done using independent sample t-test (if parametric); Mann-Whitney test for quantitative variables and Chi square or Fisher's exact test for qualitative ones. $\mathrm{P}$ values $<0.05$ considered statistically significant, and $<0.01$ were considered highly significant.

\section{Results}

The clinical data of patients are listed in Table (1). Of the $121 \mathrm{CHB}$ patients, 89 (73.6\%) were males and 32 $(26.4 \%)$ were females. The majority was in the $4^{\text {th }}$ decade of life (patients' mean age was $33.7 \pm 10.6$ years) and overweight with body mass index (BMI) $28.0 \pm 5.6$ $\mathrm{Kg} / \mathrm{m}^{2}$.

Surgical interference was found to be the major risk factor representing $47.1 \%$ of the cases, followed by dental extraction and history of blood transfusion $(8.3 \%$ and $4.1 \%$ respectively). Parenteral anti-schistosomal treatment and intravenous drug use were not found to be major risk factors ( $<1 \%$ each).

Among the 121 patients, 97 (80.1\%) were HBeAg-negative and 24 (19.9\%) were HBeAg-positive. HBeAg-neg- ative patients were significantly older in age $35.3 \pm$ 10.4 years versus $27.3 \pm 9.0$ years in CHBeAg-positive $(\mathrm{p}=0.001)$. There was no statistically significant difference in sex.

ALT levels in $\mathrm{HBeAg-negative} \mathrm{patients} \mathrm{were} \mathrm{significant-}$ ly lower than those in HBeAg-positive patients (39.2 \pm 30.1) $\mathrm{U} / \mathrm{L}$ vs. $(52.9 \pm 33.5) \mathrm{U} / \mathrm{L}, \mathrm{p}=0.02$, whereas serum albumin was lower in the $\mathrm{HBeAg}$-positive group $(4.1 \pm 0.4 \mathrm{~g} / \mathrm{dL}$ vs. $4.3 \pm 0.6 \mathrm{~g} / \mathrm{dL}, \mathrm{p}=0.03)$. Serum bilirubin and international normalized ratio (INR) showed no statistical difference between both groups.

The proportion of patients with HBV DNA levels higher than $2 \times 10^{4} \mathrm{IU} / \mathrm{mL}$ in $\mathrm{HBeAg}$-negative patients was lower than those in the $\mathrm{HBeAg}$-positive patients (68\% vs. $87.5 \%, p=0.24)$. Among the studied population, genotype sequence analysis for HBV showed that HBV-genotype D was present in all patients

Evaluating stages of fibrosis by TE showed that $30.9 \%$ of patients of $\mathrm{HBeAg}$-negative group and $41.7 \%$ of patients of $\mathrm{HBeAg}$-positive group had moderate to severe fibrosis $(>$ F2), yet this difference was not statistically significant $(p=0.29)$. TE could not be done for 7 patients because of their obesity, and one patient for being pregnant. Four patients $(3.3 \%)$ were diagnosed with HCC; all of them were $\mathrm{HBeAg-negative.}$

Among the studied population, liver biopsy was done for 10 patients. All of them were A1 and 7 were F1 $(70 \%)$. Out of the 7 patients with F1 by biopsy, 4 were F2-F3 by TE and 3 were F0-F1. 
Table 1: Demographic, Laboratory and Histological Characteristics of the Study Population $^{\text {a }}$

\begin{tabular}{|c|c|c|c|c|}
\hline & $\begin{array}{l}\text { All patients } \\
(\mathrm{n}=121)\end{array}$ & $\begin{array}{l}\text { HBeAg-Negative } \\
\text { Patients (n=97) }\end{array}$ & $\begin{array}{l}\text { HBeAg-Positive } \\
\text { Patients }(n=24)\end{array}$ & P-value \\
\hline $\begin{array}{ll}\text { Sex } \\
\text { - } \\
\text { - } \quad \text { Female }\end{array}$ & $\begin{array}{l}89(73.6 \%) \\
32(26.4 \%)\end{array}$ & $\begin{array}{l}71(73.2 \%) \\
26(26.8 \%)\end{array}$ & $\begin{array}{c}18(75 \%) \\
6(25 \%)\end{array}$ & 0.86 \\
\hline Age, years & $33.71 \pm 10.63$ & $35.3 \pm 10.4$ & $27.3 \pm 9.0$ & 0.001 \\
\hline Body mass index $\left(\mathrm{kg} / \mathrm{m}^{2}\right)$ & $28.02 \pm 5.59$ & $28.00 \pm 5.82$ & $28.13 \pm 4.63$ & 0.85 \\
\hline Serum ALT(U/L) & $41.92 \pm 31.11$ & $39.20 \pm 30.05$ & $52.92 \pm 33.52$ & 0.02 \\
\hline Serum AST(U/L) & $37.42 \pm 28.73$ & $35.77 \pm 28.88$ & $44.08 \pm 27.72$ & 0.05 \\
\hline Serum total bilirubin(mg/dL) & $0.94 \pm 2.25$ & $1.01 \pm 2.50$ & $0.67 \pm 0.27$ & 0.87 \\
\hline Serum direct bilirubin $(\mathrm{mg} / \mathrm{dL})$ & $0.45 \pm 1.83$ & $0.51 \pm 2.04$ & $0.22 \pm 0.15$ & 0.61 \\
\hline Serum albumin(g/dL) & $4.21 \pm 0.54$ & $4.25 \pm 0.55$ & $4.06 \pm 0.44$ & 0.03 \\
\hline International normalized ratio & $1.11 \pm 0.18$ & $1.10 \pm 0.18$ & $1.14 \pm 0.17$ & 0.06 \\
\hline Ascites & $2(1.6 \%)$ & $2(2.1 \%)$ & $0(0 \%)$ & 1.0 \\
\hline $\begin{array}{l}\text { Phase of natural history } \\
\text { - Immune-tolerant } \\
\text { - HBeAg-positive immune-active } \\
\text { - Inactive CHB } \\
\text { - HBeAg-negative immune } \\
\text { reactivation phase }\end{array}$ & $\begin{array}{l}11(9.1 \%) \\
13(10.7 \%) \\
37(30.6 \%) \\
60(49.6 \%)\end{array}$ & $\begin{array}{c}- \\
- \\
37(38.1 \%) \\
60(61.9 \%)\end{array}$ & $\begin{array}{c}11(45.8 \%) \\
13(54.2 \%) \\
- \\
-\end{array}$ & \\
\hline $\begin{array}{l}\text { HBV DNA (IU/mL) } \\
\text { - } \quad \text { Undetectable }(<15) \\
\text { - } \quad<2000 \\
\text { - } \quad 2000-20000 \\
\text { - } \quad>20000\end{array}$ & $\begin{array}{l}18(14.9 \%) \\
9(7.4 \%) \\
7(5.8 \%) \\
87(71.9 \%)\end{array}$ & $\begin{array}{c}16(16.5 \%) \\
9(9.3 \%) \\
6(6.2 \%) \\
66(68.0 \%)\end{array}$ & $\begin{array}{c}2(8.3 \%) \\
0(0 \%) \\
1(4.2 \%) \\
21(87.5 \%)\end{array}$ & 0.24 \\
\hline Liver fibrosis by TE $(\mathrm{kPa})$ & $7.08 \pm 3.22$ & $6.98 \pm 3.16$ & $7.53 \pm 3.52$ & 0.25 \\
\hline 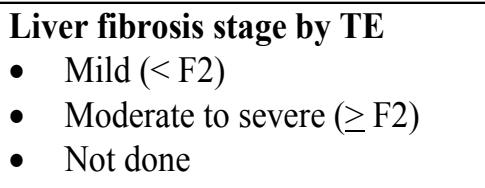 & $\begin{array}{c}73(60.3 \%) \\
40(33.1 \%) \\
8(6.6 \%)\end{array}$ & $\begin{array}{c}61(62.9 \%) \\
30(30.9 \%) \\
6 \quad(6.2 \%)\end{array}$ & $\begin{array}{c}12(50.0 \%) \\
10(41.7 \%) \\
2(8.3 \%)\end{array}$ & 0.29 \\
\hline HCC & $4(3.3 \%)$ & $4(4.1 \%)$ & $0(0 \%)$ & 1.0 \\
\hline
\end{tabular}

a Data are presented as No. (\%) or Mean \pm SD

b Interpretation of the natural history according to AASLD guidelines for treatment of chronic hepatitis B [AASLD Guidelines, 2016]

\section{Discussion}

The current study demonstrated a high prevalence of $\mathrm{HBeAg-negative} \mathrm{CHB} \mathrm{in} \mathrm{Egypt.} \mathrm{Among} \mathrm{the} 121$ HBsAg positive patients included in the study, 97
(80.1\%) were HBeAg-negative and 24 (19.9\%) were HBeAg-positive. This high prevalence of HBeAg-negative $\mathrm{CHB}$ was reported in the Mediterranean region, including Egypt in which a study among $52 \mathrm{HBsAg}$ 
positive patients, detected only $4 \mathrm{HBeAg}$ positive patients $(7.6 \%)^{14}$. Both HBeAg seroconversion and development of $\mathrm{HBeAg}$-negative $\mathrm{CHB}$ have been assumed to be associated with the infecting HBV genotypes ${ }^{15}$. $\mathrm{HBeAg}$ seroconversion appears to occur sooner and $\mathrm{HBeAg-negative} \mathrm{CHB}$ appears to develop more frequently in patients infected with genotype D compared with genotypes $\mathrm{A}$ or $\mathrm{C}^{16}$.

In Egypt, although HBV sequences have not been evaluated sufficiently, most studies report that genotype D is the prevalent genotype in Egypt, the clinical impact of which has been studied less extensively ${ }^{17,18}$. Similar results were found in our study, as all patients were genotype D2. Differences in prevalence of e-CHB in different regions may be in part related to geographical variation in $\mathrm{HBV}$ genotypes ${ }^{7}$. In $\mathrm{HBV}$ genotype $\mathrm{A}$, cytosine is present at position 1858 (C-1858) precluding the selection of the G1896A mutation ${ }^{19}$. This explains the low frequency of precore mutants in regions where genotype $A$ predominates ${ }^{20}$. In contrast, the non- $A$ HBV genotypes (B, C, D, and E) harbor thymidine at the same position (T-1858), which pairs with A at 1896. Thus, precore mutants prevail in the Mediterranean where non-A genotypes, particularly $\mathrm{D}$, are predominant ${ }^{21}$.

In our cohort, there was no statistically significant difference regarding sex, but $\mathrm{HBeAg}$-negative patients were significantly older in age than $\mathrm{CHBeAg}$-positive ( $p=0.001)$.Patients with HBeAg-negative CHB are usually older than patients with $\mathrm{HBeAg}$-positive $\mathrm{CHB}$ in most series. Chu and Liaw 2007 reported that persistent $\mathrm{HBeAg}$ seropositivity beyond 40 years of age is relatively uncommon and is associated with a higher risk of cirrhosis and $\mathrm{HCC}^{22}$.

In the present study, patients with $\mathrm{HBeAg-negative}$ CHB had significantly lower ALT levels and higher albumin than $\mathrm{HBeAg}$-positive patients. We did not find any significant difference in bilirubin levels or INR between the two studied groups. A previous study reported higher levels of ALT, AST and bilirubin in HBAg-negative $\mathrm{CHB}$ patients compared to $\mathrm{HBeAg}$-positive $\mathrm{CHB}$ individuals ${ }^{23}$ whereas, a Chinese study showed higher levels of ALT in $\mathrm{HBeAg}$-positive $\mathrm{CHB}$ than in $\mathrm{HBeAg}$-negative $\mathrm{CHB}$ individuals ${ }^{24}$.

The relationship between pre-core/core promoter variants, serum HBV DNA levels, and severity of liver dis- ease is unclear ${ }^{25}$. Different studies have reported that $\mathrm{HBeAg-positiveCHB}$ patients tend to have higher viral load than $\mathrm{HBeAg}$-negative $\mathrm{CHB}$ cases ${ }^{26}$. In a study by Chu et al. 2002, among CHB patients, HBV DNA level of more than $2 \times 10^{4} \mathrm{IU} / \mathrm{mL}$ was detected in $96 \%$ of $\mathrm{HBeAg}$-positive cases ${ }^{27}$. In our study, a significant proportion $(87.5 \%)$ of $\mathrm{HBeAg}$-positive patients had HBV DNA levels of more than $2 \times 10^{4} \mathrm{IU} / \mathrm{mL}$ but this was not significantly higher than HBV DNA levels in HBeAg-negative patients $(68 \%)$

Although we found no significant difference in fibrosis scores as evaluated by TE according to the patients' $\mathrm{HBeAg}$ status, $30.9 \%$ patients of $\mathrm{HBeAg}$-negative group and $41.7 \%$ patients of $\mathrm{HBeAg}$-positive group had a fibrosis score of $>F 2$. A study from China found that hepatic necroinflammation grading and fibrosis staging in the HBeAg-negative group were more advanced than in the $\mathrm{HBeAg}$-positive group ${ }^{24}$. In another study, the HBeAg status had no association with the grade of liver inflammation and the stage of liver fibrosis in CHB patients ${ }^{28}$. However, owing to the limited indications of liver biopsy, TE could not be as accurate.

Lapalus et al. 2015 confirmed that the basal core promoter mutant is associated with a higher risk of the progression of fibrosis and that the high relative risk ( $>$ 6-fold increase) suggests that these mutations may identify patients with significant fibrosis $(F>2)$ better than HBV genotype ${ }^{29}$.

Despite its seemingly indolent course for years, $\mathrm{HBeAg}$-negative $\mathrm{CHB}$ represents a potentially progressive form of chronic liver disease. The risk of cirrhosis is higher in HBeAg-negative than HBeAg-positive $\mathrm{CHB}$, and is estimated to be 8 to 10 compared with 2 to 5 per 100 patient-years, respectively ${ }^{26}$. Moreover, the cumulative 5 -year incidence of cirrhosis has been reported to be $40 \%$ in $\mathrm{HBeAg}$-negative and 8 to $20 \%$ in HBeAg-positive CHB patients ${ }^{30}$.

In our cohort, 4 patients were diagnosed with HCC, all of whom were $\mathrm{HBeAg}$-negative. The risk of HCC is increased in patients with $\mathrm{HBeAg}$-negative $\mathrm{CHB}$, who often have common host risk factors for HCC, such as old age and male gender ${ }^{31}$. In a Greek cohort, the 4-year mortality from HCC was found to be $14 \%$ in patients with $\mathrm{HBeAg}$-negative $\mathrm{CHB}, 4 \%$ in $\mathrm{HBeAg}$-positive patients, and $2 \%$ in chronic inactive HBsAg carriers $^{32}$. Also, both $\mathrm{HBeAg-negative} \mathrm{genomic} \mathrm{variants}$ have been reported to be associated with advanced liver disease and the development of $\mathrm{HCC}^{33}$. 
This study expresses few limitations including few numbers of patients who underwent a liver biopsy and lack of follow-up period.

\section{Conclusion}

HBeAg status might be considered as one of the key factors that influence the complex relationship between serum HBV DNA level and liver inflammation and fibrosis; thus affecting the outcome of chronic hepatitis B.

\section{Conflict of interest}

None to be declared.

\section{Funding source}

This research did not receive any specific grant from funding agencies in the public, commercial, or not-forprofit sectors.

\section{References}

1. Perz JF, Armstrong GL, Farrington LA, Hutin YJ, Bell BP. The contributions of hepatitis B virus and hepatitis $C$ virus infections to cirrhosis and primary liver cancer worldwide. J Hepatol 2006; 45 (4): 529-538

2. El Zayadi AR, Badran H, Barakat EM, Attia Mel-D, Shawky S, Mohamed MK, Selim et al. Hepatocellular carcinoma in Egypt: A single center study over a decade. World J Gastroenterol 2005; 11 (33): 5193-8

3. Fattovich G, Bortolotti F, Donato F. Natural history of chronic hepatitis B: special emphasis on disease progression and prognostic factors. J Hepatol 2008; 48 (2): 335-52.

4. McMahon B. Epidemiology and natural history of hepatitis B. Semin Liver Dis. 2005; 25 Suppl 1: 3-8

5. Lok A and McMahon B. Chronic Hepatitis B. Hepatology 2007; 45 (2): 507-39

6. Krajden M, McNabb G, Petric M. The laboratory diagnosis of hepatitis B virus. Can J Infect Dis Med Microbiol 2005; 16 (2): 65-72

7. Funk ML, Rosenberg DM, Lok AS. World-wide epidemiology of HBeAg-negative chronic hepatitis B and associated precore and core promoter variants. $J$ Viral Hepat. 2002; 9 (1): 52-61

8. Ribeiro R, Germanidis G, Powers K, Pellegrin B, Nikolaidis P, Perelson A et al. Hepatitis B virus kinetics under antiviral therapy sheds light on differences in hepatitis B e antigen positive and negative infections. $J$ Infect Dis. 2010; 202 (9): 1309-1318

9. Yuan H, Yuen M, Wong K, Sum S, Sablon E, Ng IO, Lai C. Impact of precore and core promoter mutations on hepatic histology in patients with chronic hepatitis B. Aliment Pharmacol Ther 2005; 22 (4): 301-307
10. Papatheodoridis GV, Hadziyannis SJ. Diagnosis and management of pre-core mutant chronic hepatitis B. J Viral Hepatitis 2001; 8 (5): 311-21.

11. Hadziyannis S, Papatheodoridis G, Vassilopoulos D. Treatment of HBeAg-negative chronic hepatitis B. Semin Liver Dis. 2003; 23 (1): 81-88

12. De Lédinghen V, Vergniol J. Transient elastography (FibroScan). Gastroenterol Clin Biol. 2008 Sep;32(6 Suppl 1):58-67.

13. European Association for the Study of the Liver. EASL Clinical Practice Guidelines: Management of chronic hepatitis B virus infection. J Hepatol 2012; 57 (1):167-85.

14. Kader O, Metwally DE, Helaly GF, El-Batouti GA, Hassan MB, Elsawaf R. Mutation in the precore region of HBV in chronic hepatitis B patients. J Am Sci 2013; 9 (5): 157-162

15. Kramvis A, Kew MC. Relationship of genotypes of hepatitis B virus to mutations, disease progression and response to antiviral therapy. J Viral Hepat 2005; 12 (5): 456-464

16. Tanaka Y, Hasegawa I, Kato T, Orito E, Hirashima $\mathrm{N}$, Acharya SK et al. A case-control study for differences among hepatitis B virus infections of genotypes A (subtypes Aa and Ae) and D. Hepatology 2004; 40 (3): 747-755

17. Saudy N, Sugauchi F, Tanaka Y, Suzuki S, Abdel Aal A, Abo Zaid M et al. Genotypes and phylogenetic characterization of hepatitis B and delta viruses in Egypt. J. Med. Virol. 2003; 70 (4): 529-536

18. Habil F, Mahdi W, Abdelwahab S, Abdel-Hamid M. Hepatitis B virus genotype D predominates HBsAg-positive Egyptian blood donors and is mainly associated with a negative $\mathrm{HBeAg}$ serostatus. Intervirology 2013; 56 (5):278-283

19. Sung JJ, Chan HL, Wong ML, Tse CH, Yuen SC, Tam JS et al. Relationship of clinical and virological factors with hepatitis activity in hepatitis B e antigen-negative chronic hepatitis B virus-infected patients. J Viral Hepat. 2002; 9 (3): 229-234

20. Lindh M, Andersson AS, Gusdal A. Genotypes, nt 1858 variants, and geographic origin of hepatitis B virus-large scale analysis using a new genotyping method. J. Infect. Dis.1997; 175 (6): 1285-1293

21. Laras A, Koskinas J, Avgidis K, Hadziyannis SJ. Incidence and clinical significance of hepatitis B virus precore gene translation initiation mutations in e antigen-negative patients. J. Viral Hepat. 1998; 5 (4): 241248

22. Chu C, Liaw Y. Chronic hepatitis B virus infection acquired in childhood: special emphasis on prognostic 
and therapeutic implication of delayed HbeAg seroconversion. J Viral Hepat. 2007; 14 (3): 147-52

23. Bahramali G, Sadeghizadeh M, Amini-Bavil-Olyaee S, Alavian SM, Behzad-Behbahani A, Adeli A et al. Clinical, virologic and phylogenetic features of hepatitis B infection in Iranian patients. World J Gastroenterol. 2008; 14 (35): 5448-53

24. Yang CG, Yu YC, Chen JJ, Sun J, Guo YB, Luo $\mathrm{KX}$ et al. A comparison of clinical and virological characteristics of 1686 cases of $\mathrm{HBeAg}$ negative and $\mathrm{HBeAg-positive} \mathrm{chronic} \mathrm{hepatitis} \mathrm{B.} \mathrm{Zhonghua} \mathrm{Nei} \mathrm{Ke} \mathrm{Za}$ Zhi. 2005; 44 (9): 648-51

25. Jalali M, Alavian S. Hepatitis B e Antigen-Negative Chronic Hepatitis B. Hepat Mon 2006; 6 (1): 31-35

26. Hadziyannis S, Papatheodoridis G. Hepatitis B e antigen-negative chronic hepatitis $\mathrm{B}$ : natural history and treatment. Semin Liver Dis. 2006; 26 (2):130-141

27. Chu C, Hussain M, Lok A. Quantitative serum HBV DNA levels during different stages of chronic hepatitis B infection. Hepatology 2002; 36 (6): 1408-15

28. Liu SQ, Zhu XJ, Sun XH, Li M, Gao YQ. Characteristic of liver pathology in $\mathrm{HBeAg}$-positive and $\mathrm{HBeAg}$-negative chronic hepatitis B patients with mildly elevated ALT. Zhonghua Gan Zang Bing Za Zhi. 2012; 20 (5): 34-52
29. Lapalus M, Laouenan C, Cardoso AC, Estrabaud E, Carvalho-Filho RJ, Zhang Q et al. Precore/Core promoter variants to predict significant fibrosis in both $\mathrm{HBeAg}$ positive and negative chronic hepatitis B. Liver Int. 2015; 35 (9): 2082-2089

30. Hsu YS, Chien RN, Yeh CT, Sheen IS, Chiou HY, Chu CM et al. Long-term outcome after spontaneous $\mathrm{HBeAg}$ seroconversion in patients with chronic hepatitis B. Hepatology 2002; 35 (6): 1522-1527

31. Lin CL, Liao LY, Wang CS, Chen PJ, Lai MY, Chen DS et al. Basal core-promoter mutant of hepatitis $B$ virus and progression of liver disease in hepatitis B e antigen-negative chronic hepatitis B. Liver Int. 2005;25(3):564-70.

32. Hadziyannis SJ, Bramou T, Alexopoulou A, Makris A. Immunopathogenesis and natural course of anti-HBe positive chronic hepatitis and natural course of anti-HBe positive chronic hepatitis with replicating B virus. In: Hollinger FB, Lemon SM, Margolis H, editors. Viral Hepatitis and Liver Disease. Baltimore: Williams and Wilkins; 1991. pp. 673-676.

33. Kao JH, Chen PJ, Lai MY, Chen DS. Basal core promoter mutations of hepatitis $\mathrm{B}$ virus increase the risk of hepatocellular carcinoma in hepatitis B carriers. Gastroenterology 2003; 124 (2): 327-34. 